\title{
Os Tangos Urbanos no Rio de Janeiro: 1870-1920 Uma Análise Histórica e Musical
}

\author{
Paulo Roberto Peloso Augusto
}

\section{Relações entre Música Popular e Poder}

A partir da década de 1870 , podemos observar, no âmbito da cidade do Rio de Janeiro, o surgimento de novos gêneros musicais populares, que representaram, desde então, a fala de uma nova classe que se afirmava e uma proposta artística original, assim observada tendo em vista a cristalização de uma nova estética musical urbana. $\mathrm{O}$ ambiente cultural deste momento, e em especial na virada do século, ocupado em todos os setores pela classe dominante, não privilegiava ou sequer permitia as manifestações culturais populares, estas vistas então como sinal e expressão do atraso em que estava imerso o país. Esta hostilidade implicava a adesão a um modelo de desenvolvimento e progresso, representado pela cultura francesa, e ao consumo, tanto de produtos e mercadorias quanto de músicas da moda parisiense, assim como o gosto pelas demais manifestações artístico-culturais daquela metrópole. A elite burguesa brasileira transformou os salões familiares e os teatros em espaços de auto-reconhecimento, tomando por paradigma sempre o código artístico-musical francês, através do qual se expressava, negando a validade de um outro código, 
principalmente o que fosse advindo das camadas subalternas, que recordavam uma realidade a ser esquecida.

Este preconceito, entretanto, não colidia com a afirmação do ideal de nação brasileira ou conceito de brasilidade, uma vez que, segundo a óptica da elite dominante, ao se promover o progresso e o desenvolvimento do Brasil de acordo com cânones da metrópole francesa, a nação encontraria assim a sua identidade mais genuína. $\mathrm{Na}$ realidade, era um ideal da burguesia brasileira participar da chamada sociedade civilizada.

Neste momento, em que o músico popular é excluído do processo de construção da nação pela elite brasileira, a música popular urbana, que surge no Rio de Janeiro, apresenta uma nova proposta estética, caracterizada na seguinte fusão: de um lado, o aproveitamento das formas musicais em voga na Europa para a dança e o canto, como, por exemplo, a polca; por outro lado, a introdução de novas expressões rítmico-melódicas e harmônicas, que viriam consolidar uma nova estética musical urbana, ou seja, um contraponto aos ideais estéticos europeizantes das elites.

Como afirmamos, estes novos gêneros populares, como o tango, derivavam, na realidade, de composições de sucesso na Europa, especialmente em Paris. Observamos que o tango, antes de ser acolhido pelas platéias cariocas, no início da década de 1870 , já fazia enorme sucesso nos teatros parisienses, tendo, por isso mesmo, interessado a compositores brasileiros, como Henrique Alves de Mesquita, que logo o introduziram em suas operetas.

Esta predileção nos revela, também, que as camadas subalternas, longe de rejeitarem por completo o código musical das elites e em especial seus gêneros musicais favoritos - como forma de resistência à dominação e discriminação - , assimilaram no discurso musical popular elementos importantes das falas dominantes, como as próprias formas musicais, com todas as implicações tonais, rítmicas e culturais.

Um outro elemento forte de assimilação dessas falas pela música popular foi a incorporação do piano no conjunto instrumental do Choro. Este último possuiu, sem dúvida, a formação que melhor 
caracterizaria a música popular urbana na chamada belle époque: flauta, violão, cavaquinho, entre outras possibilidades, com a participação do piano, que se tornou indispensável em conjuntos de choro, como o de Chiquinha Gonzaga.

A incorporação do piano teria um significado especial. $\mathrm{Na}$ realidade, tratava-se de um símbolo importante, não somente musical, mas principalmente de poder e de ascensão social. Isto porque o piano era o símbolo de status da burguesia européia e veículo privilegiado do código musical burguês dominante: o romantismo.

Podemos observar, então, que a interpretação de obras populares ao piano, a aquisição deste instrumento - de preço elevado - e a localização do mesmo, em lugar de destaque nas salas das casas de família, bem como a estilização de diversos gêneros oriundos da elite, sinalizavam um indicativo de promoção ou integração social. Estava, assim, o músico popular em busca da respeitabilidade, sem se opor frontalmente à música da classe dominante, símbolo da repressão.

Assim, observamos um diálogo entre a música popular e a da elite, em que há mais sintonias do que oposições radicais, propriamente ditas. Notamos uma aproximação das falas, pela incorporação de diversos códigos musicais existentes, que serão analisados neste artigo. O signo musical, contudo, é polissêmico, devendo-se ter cautela na análise destas comparações, que remetem; por vezes, ao campo subjetivo das interpretações.

\section{O Tango Brasileiro}

Dentre as várias manifestações musicais que podemos localizar na cidade do Rio de Janeiro, no período compreendido entre 18701920, destacamos o gênero tango, pela grande repercussão que obteve nos salões da época, quer populares, quer da elite.

Contudo, ao observarmos seus antecedentes formais, a sua duração enquanto gênero musical, com todas as suas variantes 
criadas e, finalmente, os gêneros que lhe sucederam e que influenciaram o gosto musical popular, citamos Zamacois, quando se pronuncia sobre a transformação e renovação dos tipos formais:

${ }^{6 C}$ Cada tipo formal tem sua história - curta ou longa -, e esta não pode dar-se nunca por definitivamente encerrada, pois os compositores, com bastante freqüência, voltam ao antigo e esquecido, aspirando dar-lhe novas aparências. Ademais, em cada tipo formal devem registrar-se seus períodos de gestação, desenvolvimento, crescimento, etc. Houve tipos formais que desapareceram sem deixar rastro; outros houve que frutificaram $\mathrm{e}$ deram seiva a outros, c há os que sobrevivem, com maior ou menor força. Nenhum tipo formal de longa história pôde, como é lógico, permanecer invariável através dela. Não há, pois, que esperar, por exemplo, que uma sonata de hoje se ajuste aos moldes das primitivas e nem sequer das beethovenianas. Aqui, como em tudo, "renovarse ou morrer"l.

Podemos, assim, observar que o gênero tango nunca apresentou uma estrutura modelar fixa, variando muito a célula rítmica geradora, o andamento, a forma e a própria denominação, já que os títulos faziam, freqüentemente, alusão a outras danças. Daí ser mais apropriado falar em "tangos brasileiros".

Na década de 1870, o Rio de Janeiro assistiria à representação, em teatro, de uma nova dança: a havanera. Em 1871, o maestro Henrique Alves de Mesquita, ao adaptar duas havaneras espanholas da peça "O jovem Telêmaco", deu-lhes o nome de tango, termo este utilizado pelo francês Lucien Boucquet em composição própria em 1863.

A havanera, popularizada em Havana, Cuba, logo foi difundida na Espanha e o seu ritmo característico no acompanhamento -. $:$ era o mesmo do tango, este na origem uma dança mexicana, que se diferenciava basicamente da havanera pela variação no andamento, acelerando aos poucos até acabar abruptamente. Da mesma forma que a havanera, o tango mexicano difundiu-se na Espanha; ambas as danças foram posteriormente 
executadas em números teatrais em Paris, de onde Henrique Alves de Mesquita foi buscar o modelo para compor, então, o primeiro tango brasileiro, o qual denominou "Olhos matadores", no mesmo ano em que fizeram sucesso as suas transcrições das duas havaneras espanholas, ou seja 1871 , conforme relacionamos anteriormente.

Efetivamente, a acolhida do público a este novo gênero foi calorosa, tanto assim que no ano seguinte, 1872, Mesquita compunha outro tango, agora para uma peça teatral, intitulado "Ali-babá ou os quarenta ladrões", que obteve uma tal receptividade, que levou Machado de Assis a escrever na Semana Illustrada: "Ninguém se mata porque não tirou a sorte ou porque perdeu o primeiro ato do Ali-babá do Mesquita".

Nesta obra, o Ali-babá, as características do tango nativo mexicano, recém-chegado ao Brasil após um longo percurso via Espanha-Paris-Rio, são bem explicitadas, ou seja, é uma composição que se inicia em andamento moderado, na segunda parte, poco piì, já está bem mais movimentado, até que nos últimos seis compassos surge a indicação stringendo o que leva a acelerar cada vez mais, concluindo abruptamente.

\section{T.A IN $\mathbf{O}$.}

PIANO

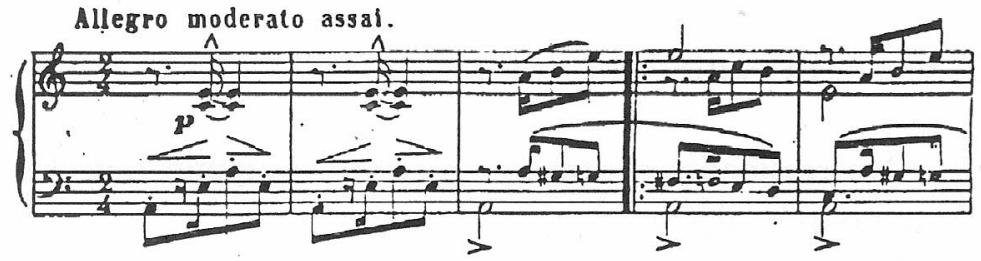

Exemplo 1

Entretanto, esta composição não tem a mesma linguagem que os similares tangos espanhóis. A célula rítmica da havanera e do tango estão presentes na primeira parte ..$?$; na melodia, podemos notar a célula freqüente no lundu, ser entendida, também, como uma transposição popular (carioca) da rítmica característica da havanera 
te, enquanto a melodia apresenta o ritmo da polca, com feições cariocas $\div$, o acompanhamento estabelece a pulsação do lundu $\longrightarrow$. Assim, esses atributos rítmicos e de pulsação não deixavam dúvidas quanto à procedência da nova dança: a música popular carioca.

Observamos, contudo, que o caráter fundamental desta composição - tango mexicano - , conforme foi descrito acima, não se repetiria mais nas composições intituladas tango, mas sim nas recorrências da havanera. Parece-nos, pois, uma incoerência a manutenção do título "tango brasileiro", que melhor significado teria se fosse nomeado "havanera brasileira".

Ao fazermos uma análise do chamado tango brasileiro, concluímos pela necessidade de se entender este gênero no plural: tangos brasileiros ${ }^{3}$. Contudo, não só devemos entender o gênero tango brasileiro no plural, como também analisar a pluralidade de interpretações válidas, a partir dos diversos componentes rítmicos e sociais que entraram em sua composição. Componentes estes que fazem referência muito diretamente às mais variadas e complexas manifestações musicais das classes menos privilegiadas, tanto quanto às músicas de salão das elites dominantes, sempre ao gosto francês.

\section{Versões Eruditas do Tango}

Na realidade, o ritmo empregado no tango e na havanera, característico destas danças e que está tão presente no tango brasileiro, não é de origem recente. Nossa busca em direção a uma possível origem, tanto nos conduziu às musicas das camadas populares da América Espanhola, no início do século XIX, como também à música aristocrática da corte francesa da época de Luís XV, com o compositor e clavecinista Rameau (1683 - 1764).

Em sua composição para cravo L'Égyptiènne, podemos observar nos compassos 17, 18, 19, 47, 48, 50, 57 (entre outros), a presença da célula rítmica. . $_{0}$ na parte inferior. Esta referência só é consignada aqui em virtude de tratar-se de uma 
dança, que no caso, recebe um tratamento preponderantemente instrumental, como outras danças da época que integravam as suítes. Não é um aproveitamento rítmico fortuito, mas sim bastante sugestivo. $\mathrm{O}$ que nos faz lembrar que grande parte das danças que integraram as suites barrocas, dirigidas a uma platéia aristocrática, tinha origem popular, mantendo, inclusive, seus títulos originais.

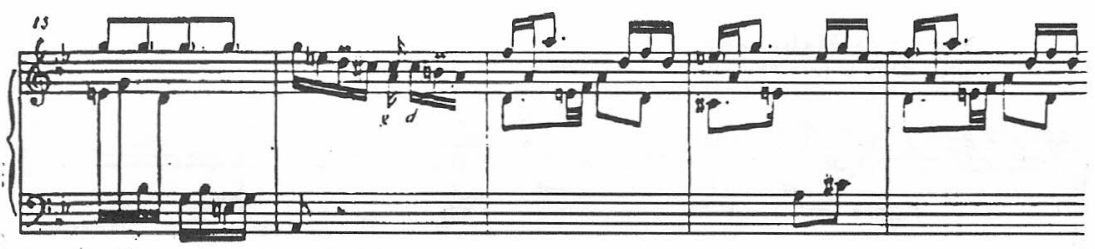

Exemplo 2

Na Espanha, o compositor e musicólogo Pedrell, da escola nacionalista, desenvolveu uma pesquisa aprofundada sobre a canção popular espanhola. Nas suas composições notamos o emprego de células rítmicas específicas das danças populares, em especial do tango.

Outro compositor espanhol de expressão nacionalista, Albeniz, empregou em suas composições as células rítmicas próprias do tango. Podemos analisar, no exemplo 3, uma de suas obras para piano, intitulada tango, em que está lançada toda a problemática rítmica e estrutural. Contudo é de se notar na melodia a presença da célula rítmica Mario de Andrade, viriam, no Brasil, a se transformar em .. - _ ; um dos ritmos caraterísticos do maxixe. Esta obra pertence a uma suíte intitulada Espanha.

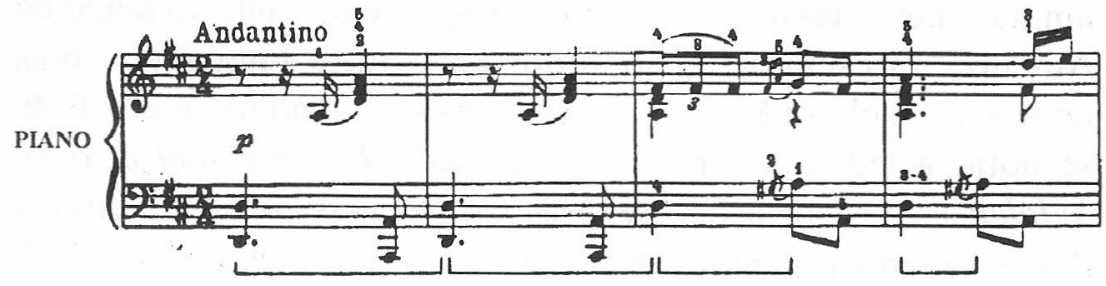

Exemplo 3 
Em Debussy (1862 - 1918), também pudemos encontrar a célula rítmica própria do tango. O Prelúdio III do segundo livro, intitulado ... La Puerta del Viño, como um dos exemplos do autor, tem a indicação expressa Mouvement de Habane e exibe claramente esta problemática, apresentando, igualmente, um viés nacionalista, com a utilização da chamada escala árabe, integrante da música popular espanhola.

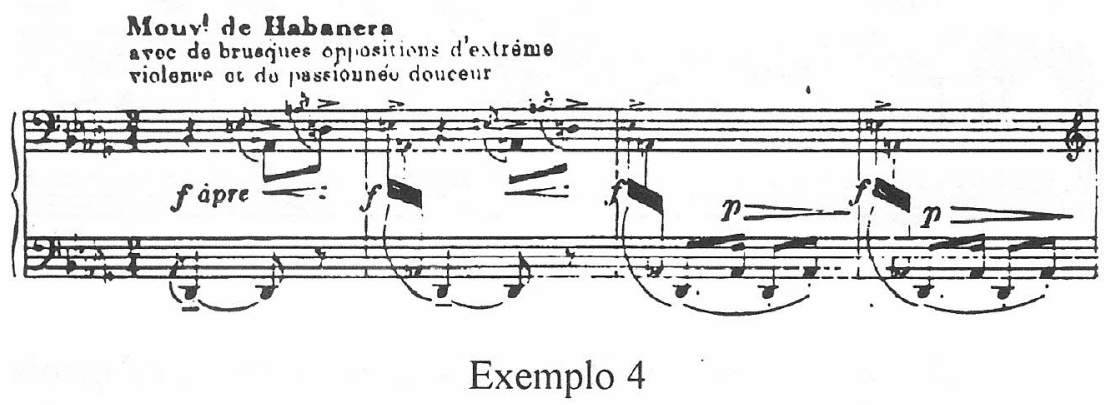

Este compositor, que empreendia a pesquisa tímbrica detalhada e a busca de sonoridades sempre novas, especificou logo no início deste prelúdio o seguinte caráter: ... avec de brusques oppositions d'extrême violence et de passionée douceur, indicando a concepção erudita destas danças populares.

Notamos que o compositor utilizou a indicação habanera e não tango. Assim, no tango brasileiro, existem mais traços do gênero havanera do que do tango, conforme mencionado anteriormente, uma vez que o tango se diferenciava da havananera pela flutuação contínua do andamento.

Nesta linha de argumentação ainda podemos citar Ravel(1875 - 1935), que em sua Pièce en forme de habanera (exemplo 5) dá um tratamento textural a esta composição semelhante ao tango de Albeniz, apresentando, contudo, uma outra linguagem, mas nomeando a obra não como tango, mas sim como havanera. É de se notar a indicação inicial do caráter ...Presque lent et avec indolence. Assemelhando-se, assim, a Debussy na escuta erudita destes gêneros populares. A se destacar a origem basca de Ravel, determinante de inúmeras alusões hispânicas em sua música. 


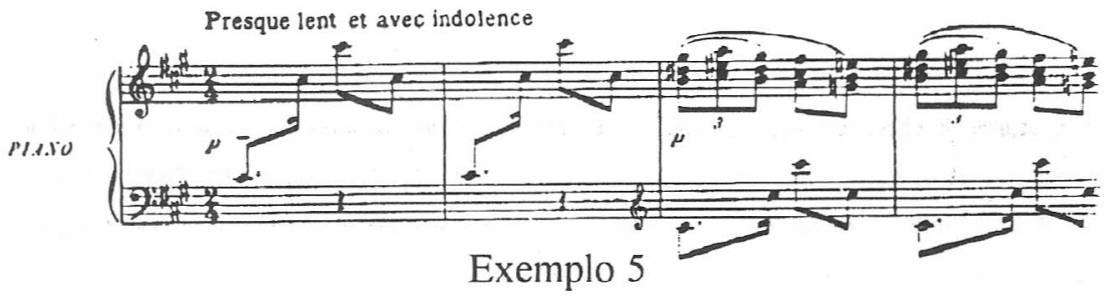

Assim como os compositores franceses precedentes, Milhaud (1892 - 1974) empregou em suas composições os ritmos próprios da havanera e do tango. Entretanto, trata-se de um compositor que residiu no Rio de Janeiro de 1916 a 1918, como secretário diplomático na missão de Paul Claudel e que pesquisou as diversas manifestações na música popular urbana carioca da época, em especial os pianeiros, que tocavam nos cinemas e por quem nutria particular interesse.

Neste caso, a observação do compositor francês foi feita a partir da audição dos tangos brasileiros, muitos deles executados por Ernesto Nazareth.

O momento histórico francês apreendia o chamado "primitivismo" das outras nações, que eram vistas como culturas que deveriam ser incorporadas sob a égide do eixo clássicoromântico europeu, passando por exóticas mas "disciplinando-se" ao contato da cultura por eles entendida superior. Um exemplo brasileiro deste primitivismo "dionisíaco" sendo submetido à esfera "apolínea" da linguagem "culta" francesa é a coletânea de obras de Milhaud, que apresenta as chamadas melodias brasileiras visando ao exotismo, como em Saudades do Brazil, onde constatamos a presença sistemática da síncopa brasileira, mas numa linguagem politonal (exemplo 6, peça Corcovado), conforme os cânones da música moderna da belle époque francesa.

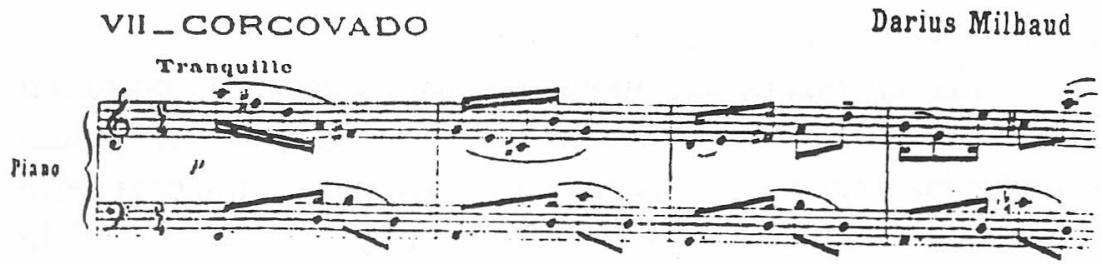

Exemplo 6 
No exemplo 7, outra comparação das estruturas da havanera e do tango de autoria do compositor e pianista alemão Moszkowsky (1854 - 1925), que escreveu dois álbuns de danças espanholas para piano. Estão presentes as mesmas estruturas rítmicas observadas no tango de Albeniz.

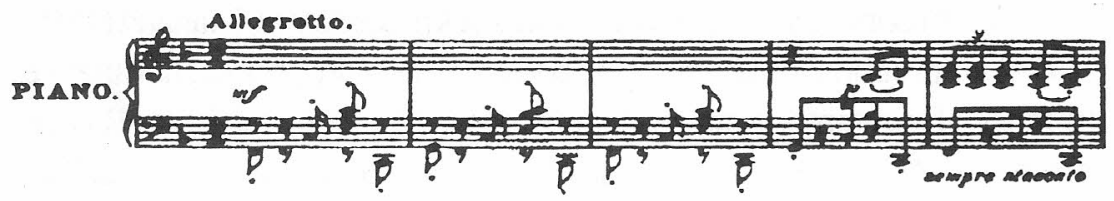

\section{Exemplo 7}

\section{Os Tangos no Rio de Janeiro}

Falamos anteriormente das possibilidades da transposição e adaptação da havanera cubano-espanhola-francesa à rítmica e linguagem da região do Rio de Janeiro. Comentaremos agora a conceituação social da dança de maior penetração popular, o maxixe (ver a ilustração da capa do maxixe carnavalesco - Bafo de Onça), que era taxada de reles, imoral e proibida pela classe dominante, sendo motivo de constrangimento público a simples citação do termo maxixe.

Em 1883, porém, o ator Francisco Correia Vasques mencionou e fez executar em público a dança proibida na peça cômica de sua autoria encenada no teatro Santana e intitulada Ai, caradura. Assim, o maxixe foi dançado para o público de classe média que comparecera ao teatro para este fim, mas a partitura do referido maxixe indicava polca-tango, o que provava que o maxixe já era divulgado através do título tango, o que era bem aceito, executado e com penetração nos salões da elite.

Uma das razões que apontamos para a aceitação do termo tango como disfarce para a música do maxixe, ou mesmo das polcas e lundus mais agitados, é justamente a proveniência francesa deste termo, que fazia sucesso nos teatros parisienses com outro conteúdo musical, como analisado anteriormente. 


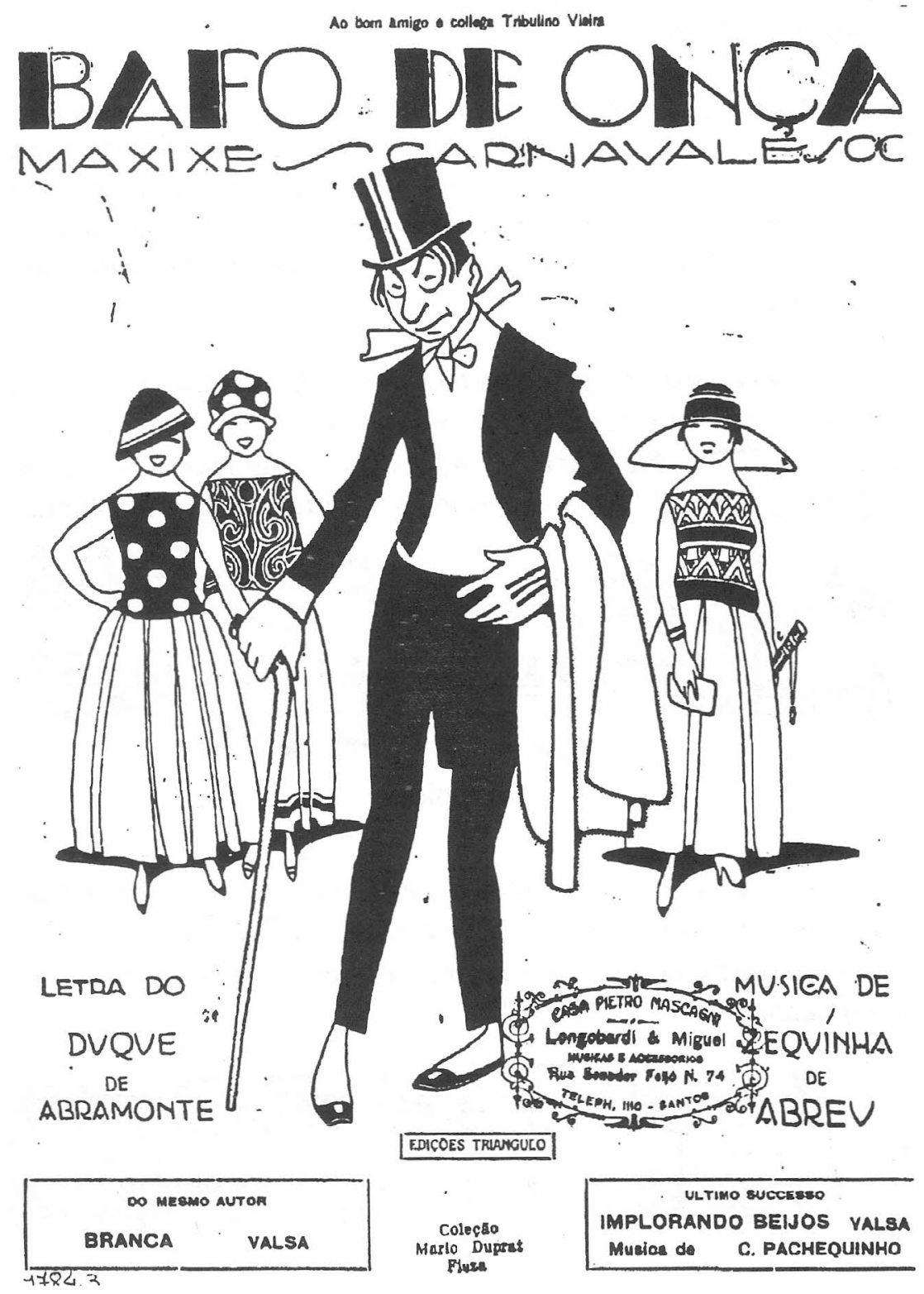


Podemos constatar uma segunda acepção para o termo tango, ou seja, como disfarce para as músicas proibidas, o que facilitava de maneira considerável aos compositores a circulação de suas partituras. Ao mesmo tempo, evitava aos intérpretes e consumidores o constrangimento da discriminação:

"Para começar, o próprio nome maxixe devido à sua origem popular de última categoria, estava, como se viu, de tal maneira ligado à noção de coisa reles e imoral, que a sua indicação ostensiva implicava necessariamente no desagrado e no veto dos compradores de partituras para piano, que eram gente da classe média para cima"4.

Só no choro - tango característico de Chiquinha Gonzaga é, na verdade, um lundu, em vista do ritmo característico. Na parte C aparece a lembrança da polca. … A nossa sugestão para o título seria polca-lundu.

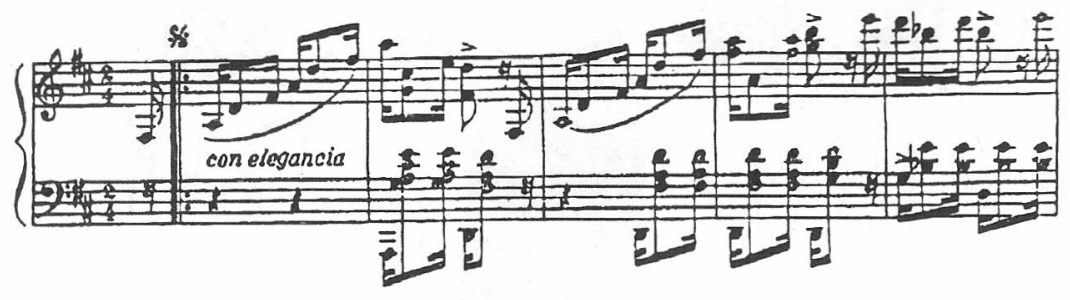

Exemplo 8

Já no tango Tupinambá de Ernesto Nazareth, o ritmo acéfalo

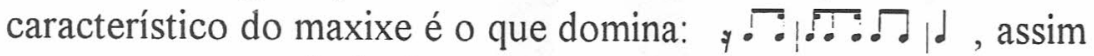
como a outra célula freqüente, também desta dança, no acompanhamento: $\check{.}$

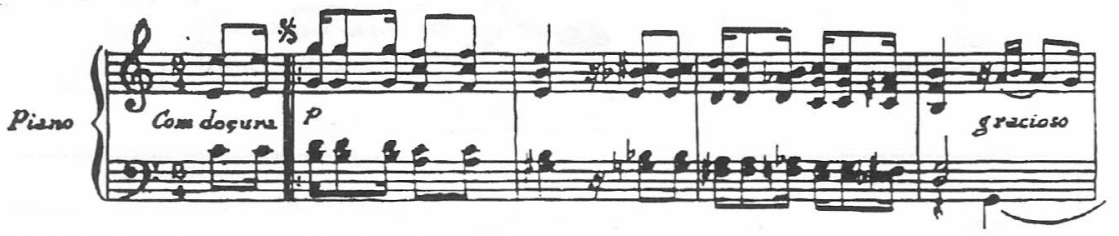

Exemplo 9 
Nazareth, contudo, rejeitava qualquer associação de suas obras com o maxixe, dizendo inclusive que as mesmas não deveriam ser dançadas, como analisaremos mais adiante. Não sendo destinadas à dança e nem ao canto, o compositor, com suas músicas, aproximava-se do ideal clássico de Música Pura.

Notamos ainda que algumas variantes são detectadas nas partituras dos diversos compositores, no período 1870-1920.

Tango, tango brasileiro (este adjetivo já é utilizado por um dos precursores da música nacionalista, Alexandre Levy [1864 1892]), tango característico, tango carnavalesco, tango meditativo, tango de salão, tango fado (que aparece na Opereta Forrobodó de Chiquinha Gonzaga), tango habanera, tango milonga, são denominações freqüentes que têm significado de acordo com o caráter derivado de cada obra. Assim o termo "característico" recorda a presença de algum ritmo de outra dança, assim como a utilização de outros adjetivos.

Mais sutil, porém, é a insistência do adjetivo "brasileiro", que não era tão freqüente, conforme pudemos apurar, mas que se tornou quase obrigatório a partir de 1914, quando o tango argentino divulgou-se rapidamente em Paris (e que contou com incentivo oficial do governo argentino). $\mathrm{O}$ adjetivo "brasileiro" também deve ser visto com reserva, uma vez que o Rio de Janeiro, tendo sido capital do Brasil, deu, muitas vezes, o designativo "brasileiro" ou "nacional" às manifestações exclusivamente cariocas e até mesmo restritas a certas regiões do Rio de Janeiro. Na realidade, estamos em presença do tango carioca ou havanera carioca.

Uma outra leitura do tango brasileiro podemos desenvolver ao observarmos sua divulgação na Europa. Quando Antônio Lopes de Amorim Diniz, O Duque, e Maria Lino divulgaram em Paris o que chamaram de le vrai tango brésilien ${ }^{5}$, em oposição ao tango argentino, na realidade dançavam o maxixe. Entretanto, estes dois dançarinos, apesar de terem alcançado grande sucesso, não apresentavam aquela coreografia "proibida", original da Cidade Nova, mas sim passos estilizados, inspirados na dança da bailarina 
Isadora Duncan, tendo sido por isso duramente criticados pela imprensa brasileira da época. Entretanto, mesmo modificada, a coreografia mantinha muito dos antigos traços, o que levou à proibição imposta pela Igreja francesa e a conseqüente fama de "dança excomungada".

\section{Possibilidades Formais do Tango}

Um destaque, na trajetória do tango brasileiro, é a obra do compositor Ernesto Nazareth. Segundo Tinhorão:

"...A idéia de mascarar o aproveitamento do maxixe com o nome de tango ia mesmo constituir, no caso especial de Ernesto Nazareth, uma verdade imprevista. Embora muitos compositores da época, como a própria Chiquinha Gonzaga, tivessem chamado seus maxixes de tango, os tangos de Nazareth seriam na verdade os únicos que mereceriam esse nome, como distintivo de uma criação particular"'.

Compartilhamos desta afirmação, uma vez que a análise das obras de Ernesto Nazareth, em confronto com as composições de seus contemporâneos, revela um conteúdo e linguagem próprios. A influência da havanera sobre este compositor, como em nenhum outro, leva-o a anotar esta designação em dois de seus tangos, sendo decisiva para que ambientasse suas músicas com as características próprias desta dança, a merecer em especial o título de tango, devido à originalidade.

Podemos, ainda, notar uma outra particularidade em Nazareth, que foi a sua formação musical fortemente clássicoromântica, o que transparece nas suas composições, que não são cantadas (à exceção de duas obras cujas letras foram acrescentadas por Catulo da Paixão Cearense) e nem foram feitas para șerem dançadas, conforme instrução do próprio compositor, que por várias vezes criticou a velocidade exagerada com que os intérpretes as executavam? 


\subsection{Tangos com ritmo de polca}

Uma das possibilidades formais mais freqüentes nas estruturas dos tangos é a apresentação do ritmo da polca, seja no acompanhamento ou na melodia. Em Ernesto Nazareth podemos observar claramente este procedimento. Por exemplo, no tango Nenê onde, após a introdução, toda a primeira parte se apresenta, no acompanhamento, com o ritmo . . . . próprio da polca. Caso semelhante, igualmente de Ernesto Nazareth, é o Choro Apanhei-te Cavaquinho, que vem intitulado em algumas edições como polca.

Na realidade, uma vez que várias polcas com a mesma estrutura rítmica, assim como outras danças, foram publicadas ou gravadas como tangos, este choro também pode e deve ser entendido como um tango, já que se adapta estruturalmente a este gênero popular. Deve-se recordar ainda que o termo choro designava mais propriamente o conjunto musical do que um tipo de composição. Nesta obra, por exemplo, são colocados em relevo dois dos instrumentos mais característicos deste conjunto: a flauta e o cavaquinho.

\subsection{Tangos com ritmo de lundu ou maxixe}

Conforme abordamos anteriormente, a coreografia do maxixe era inaceitável para a cultura de elite da época. Contudo, os compositores com o objetivo de penetrar nos salões abastados, camuflavam a dança proibida com o sugestivo e aceito título de tango, como o Corta Jaca de Chiquinha Gonzaga. Este tango, na realidade, intitula-se Gaúcho, mas é conhecido popularmente como o Corta Jaca, que é o nome de um dos passos da coreografia do maxixe.

O Gaicho apresenta constantemente pausas nos primeiros tempos dos compassos (ritmo acéfalo), traço indicativo da presença de um dos ritmos do maxixe, também encontrável freqüentemente no lundu.

A execução deste tango escandalizou as elites do início do século, quando Nair de Teffé, esposa do então presidente Marechal Hermes, interpretou-o ao violão no Palácio do Catete. 
Podemos observar em Ernesto Nazareth dois tangos que apresentam a mesma problemática do Corta Jaca, reafirmando com isso o caráter de maxixe, que por sua vez era negado terminantemente pelo compositor.

\subsection{Tangos com ritmo de havanera}

Os tangos mais usualmente conhecidos apresentam o ritmo da havanera . . . e apresentam a contradição da fusão de duas danças - o tango e a havanera - conforme abordamos anteriormente.

Outro aspecto que favoreceu a divulgação maior deste ritmo foi a semelhança com o tango argentino, que o utilizava constantemente. Entretanto, ressalvamos ainda uma vez, que esta célula rítmica é apenas uma das várias possibilidades estruturantes, de acordo com os exemplos até agora apresentados.

Em A Pera de Satanz de Henrique Alves de Mesquita, que introduziu o gênero tango no Brasil, podemos observar a presença contínua da célula ..?. . . no acompanhamento.

No tango Tim-tim de Chiquinha Gonzaga, verificamos a mesma sistemática na composição, dando ênfase às células rítmicas da havanera.

Nos dois exemplos anteriores, e ainda em Ernesto Nazareth, observamos que, apesar do ritmo constante da havanera no acompanhamento, as melodias variam os ritmos, apresentando freqüentemente a célula temática do maxixe.

Este mesmo ritmo foi o que encontramos anteriormente nos tangos e havaneras dos compositores eruditos, demonstrando, assim, uma certa preferência por esta estrutura rítmica.

\subsection{Tangos com ritmos constantes}

Uma das fórmulas rítmicas mais usuais na construção do tango era o emprego da célula $\therefore . \supset$, que em certos tangos, co- 
mo Tambyquererê de Chiquinha Gonzaga, aparece de forma constante no acompanhamento.

Este ritmo é mais um dos comprovantes de que sob o título de tango se escondia o maxixe, uma vez que é um dos mais propícios e usados nesta dança proibida. No maxixe Bafo de Onça de Zequinha de Abreu, pudemos notar justamente o emprego desta célula rítmica constante.

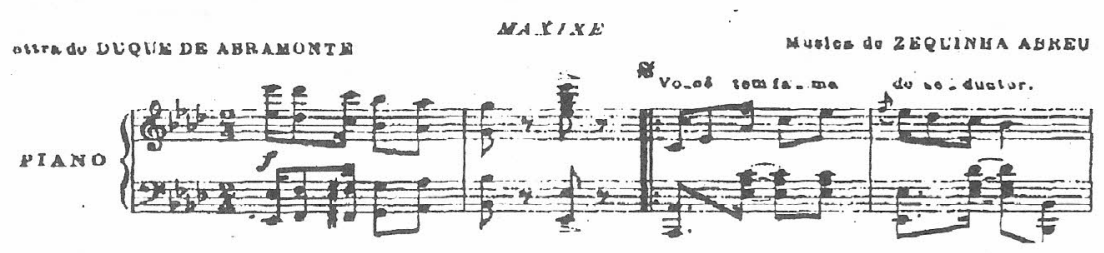

Exemplo 10

Por comparação, podemos constatar na obra de Zequinha de Abreu, Os pintinhos no terreiro, a mesma célula rítmica constante, encontrada nos tangos anteriores, com a denominação de Chorinho Sapeca. Assim como observamos semelhante emprego rítmico no tango Talisman de Ernesto Nazareth.

\subsection{Tanguinho}

Em Marcelo Tupinambá (Fernando Lobo), podemos notar uma particularidade: o acompanhamento sempre com a célula rítmica $\_. j$, tal como nos exemplos anteriores, e a denominação de tanguinho, como uma disposição afetiva. Seus títulos são de caráter melancólico, quase sempre toadas (melodia de caráter dolente).

\subsection{Tangos com ritmos combinados}

Uma outra possibilidade estrutural para os tangos era a combinação entre si, no acompanhamento e na melodia, dos ritmos 
vistos anteriormente, ou seja, de polca, lundu, maxixe, havanera e, principalmente, das variações possiveis entre eles, o que traria uma pluralidade de interpretações, no que se refere ao conhecimento da proveniência da música, como à sua execução pelo pianista. Uma amostra desta combinação está no tango Zênite de Ernesto Nazareth.

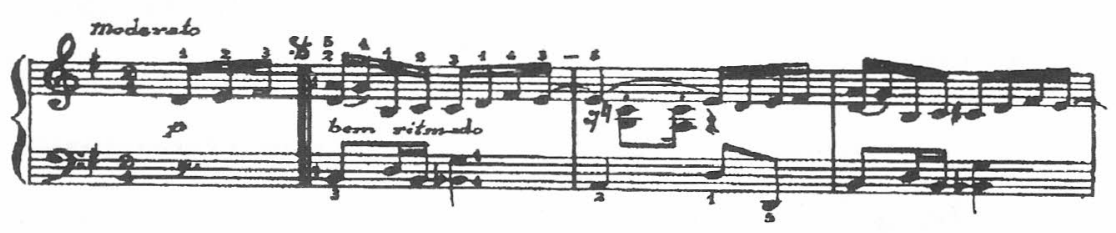

Exemplo 11

\subsection{Gêneros populares estruturalmente similares ao tango}

Conforme já citado anteriormente, podemos localizar certas composições populares, que escapam às denominações mais conhecidas, como polca, lundu, havanera, tango, maxixe, choro, mas que na realidade, estruturalmente falando, se enquadram em um desses gêneros. Com mais freqüência, podemos associar estas obras ao tango brasileiro, uma vez que como anteriormente demonstrado, este gênero possui uma pluralidade rítmica e uma associação de influências de diversas procedências.

Assim, no Candomblé, da peça Céu e inferno, de Chiquinha Gonzaga, observamos as estruturas rítmicas pertinentes ao que nos exemplos anteriores relacionamos como tango, ou seja, o caráter é o mesmo, só o título difere.

Outro exemplo desta prática é o Fado característico brasileiro Caramuru, igualmente de Chiquinha Gonzaga, no qual se introduz o nome da conhecida dança portuguesa, porém sob os ritmos próprios do tango brasileiro.

\section{A Memória Sonora}

. O tango brasileiro, conforme expusemos acima, apresenta em suas várias abordagens, ocasião de controvérsias e divergências 
acerca de sua caracterização enquanto gênero musical, desde a chamada belle époque carioca.

Freqüentemente, têm sido discutidas as recorrências formais que levaram à afirmação deste gênero, partindo de lugares comuns, tais como: Henrique Alves de Mesquita foi o "criador do tango brasileiro", em 1871, e Emesto Nazareth seu "sistematizador genial".

Problemas de ordem técnica levaram alguns musicólogos, como Bruno Kieffer, em sua obra Música e dança popular; sua influência na música erudita ${ }^{8}$, a afirmar que o tango brasileiro sempre foi um gênero completamente independente do maxixe, enquanto outros, como Tinhorão viram nesta última dança a essência do tango brasileiro, na realidade um disfarce sutil.

Outra possibilidade de diferenciação, partilhada, por exemplo, por João Chagas, seria uma distinção coreográfica:

"A sua música (do maxixe) é a música dos tangos, com um ritmo novo, introduzido no Brasil por compositores brasileiros; mas, na realidade dança-se ao som de todas as músicas, de valsas, como de marchas, árias ou canções, porque o maxixe é o ato de dançar e não a própria dança"g.

Além das partituras analisadas, observamos atentamente as gravações da época, porque nelas podemos examinar as manifestações de expressão musical com a intenção desejada pelos artistas da época.

Algumas variáveis devem ser percebidas com atenção: altura do diapasão, afinação, andamentos, licenças interpretativas, instrumentos preferidos e suas diversas formações, preferência por timbres, acentuação dos tempos, valorização de certas células rítmicas, valorização de certas linhas melódicas secundárias, marcação dos baixos e improvisações durante a execução.

Uma fonte especial para a realização desta análise sobre a produção musical da época são os discos gravados na década de 1910 (que somam quase quinhentos exemplares), localizados no acervo do Centro de pesquisas Folclóricas da Escola de Música da 
Universidade Federal do Rio de Janeiro ${ }^{10}$. Este acervo localizavase originalmente na Biblioteca Nacional, na seção dos Direitos Autorais. Nesta seção encontram-se os livros de tombo do início do século, em que se lavravam os registros de Direitos Autorais e faziam-se registros de todas e quaisquer patentes, aí incluídas as composições musicais, que eram relacionadas indiscriminadamente ao lado das mais variadas requisições de direitos autorais. Com isso, o levantamento das gravações foi dificultado por esta dispersão. Contudo, pudemos observar através dos registros, que os músicos, na maior parte das vezes, vendiam seus direitos autorais aos donos das gravadoras.

Além disso, o fato de registrarem as músicas através de discos e não de partituras, como seria mais natural supor, devia-se ao fato de esses músicos não terem possibilidade de editar a música em partitura, o que era um traço comum nestes artistas, grande parte deles autodidatas e improvisadores.

As gravadoras, na época, tiveram uma penetração muito grande em todas as camadas sociais, podendo-se provar isto, argumentando-se, que só em 1910, foram vendidos, apenas na cidade do Rio de Janeiro, mais de um milhão de discos, os quais eram gravados nesta cidade e prensados, em sua maioria, nas principais capitais européias, fato este que contribuiu, indiretamente, para a divulgação da música popular brasileira na Europa, especialmente entre as bandas militares, que incluíam em seus repertórios tangos brasileiros e maxixes, como o sucesso Vem cá mulata.

Marcas estrangeiras da recém-nascida indústria fonográfica aqui disputavam o mercado, não só gravando os discos, como vendendo-os juntamente com fonógrafos, grafofones, cilindros, gramofones, vitrolas e outros engenhos que eram superados em pouco tempo devido às modernas tecnologias ${ }^{11}$. Entre as marcas mais conhecidas estavam a Odeon Record, que tinha como sede comercial a Casa Edison, do proprietário e introdutor desta indústria no Brasil, Fred Figner; a Favorite Record, da Casa Faulhaber; a Colúmbia e a Casa Phoenix. 
Estas casas possuíam entretenimentos disputados, na época, como a exibição e audição de discos, com entrada paga. Além disso, colocavam à disposição dos compositores suas bandas e orquestras, estas últimas constituídas, às vezes, curiosamente, por quatro instrumentos.

Estes discos, em 78 rotações p.m., apresentam em sua grande maioria a voz do locutor da gravadora, anunciando em voz alta, em geral, o nome da música, o gênero correspondente, o conjunto e o nome da casa proprietária do disco. Os referidos anúncios das músicas, por parte dos locutores, tornam-se uma fonte importante de informações para os pesquisadores, tendo em vista as inúmeras contradições que são elucidativas para o debate em torno do tema tango brasileiro.

Assim, se tomarmos como exemplo a peça Afinadinho, veremos que o selo do disco traz impresso tango; no livro dos Direitos Autorais da Biblioteca Nacional está registrado polca-tango e o locutor anuncia choro. Devemos notar que a indicação dada pelos intérpretes era aquela anunciada pelo locutor, uma vez que o mesmo repetia o que os músicos lhe diziam no momento da gravação. Isto não quer dizer, contudo, que sejam as classificações definitivas, uma vez que cada denominação refletia um aspecto musical e social da composição.

Nesta composição, particularmente, o nome choro atribuído pelo locutor refere-se, uma vez mais, à maneira de tocar dos executantes (chorões) nos seus instrumentos (clarineta, cavaquinho e violão ), que imprimiam um estilo particular de interpretação, cujo caráter era denominado de choro (não como forma). O registro de polca visava ao ritmo constante e presente nesta obra . . . . , próprio desta dança. Mas o título do selo tango - seria uma garantia de venda da música, uma vez que disfarçava sutilmente a polca e o choro.

Podemos, através do registro sonoro da época, com o signo musical, estabelecer as relações entre história e música de forma interativa, conseguindo levantar e esclarecer questões que a bibliografia, tão somente, não poderia subsidiar. 
Os diversos conjuntos instrumentais podiam ter formação diversa. $\mathrm{O}$ conjunto do choro: flauta, violão e cavaquinho (e ainda clarineta e/ou oficlide). As bandas de pequeno ou grande porte e as orquestras, que às vezes apresentavam dimensões próprias de um pequeno conjunto, a que se podia somar o piano.

Em especial, devemos considerar as bandas, que às vezes pertenciam à gravadora, mas na maior parte eram militares. Integrar uma banda militar era considerado símbolo de ascensão social. Muitas vezes, estes músicos tinham patentes militares, como os bombeiros, e lhes era facultado dedicarem-se integralmente à música. Estas bandas representavam, para a maior parte da população, uma das poucas ocasiões de escutar música, fato este que propiciava prestígio e concorrência entre estes conjuntos.

Observamos que, sendo estes músicos oriundos das classes subalternas, incluíam nos repertórios destas bandas a chamada música proibida, inclusive animando bailes carnavalescos ou comemorações oficiais em que estava sempre presente o tango brasileiro.

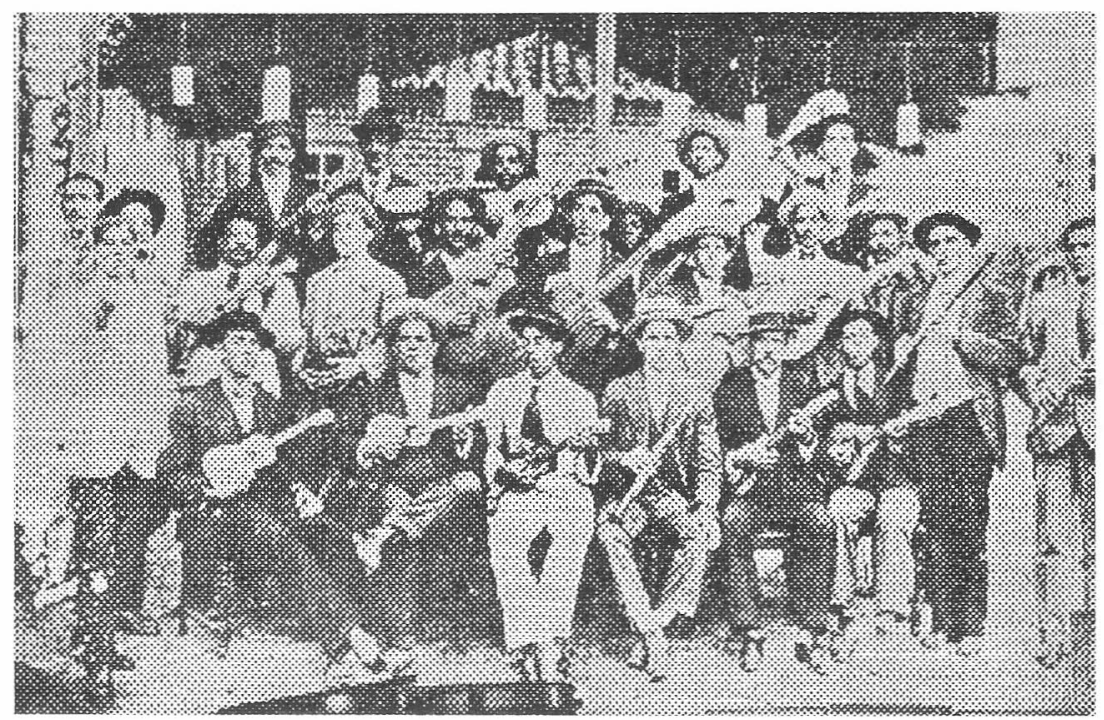


Como amostra do levantamento das partituras da época na Biblioteca Nacional, publicadas como tango brasileiro, encontramos duzentos e sessenta e cinco partituras para canto com acompanhamento instrumental; trezentas e cinqüenta para piano solo; quinze para conjunto instrumental. Estes dados refletem, proporcionalmente, que os compositores das duas primeiras categorias possivelmente dominavam a escrita musical, por isso veiculavam suas obras através de partituras. Já o terceiro grupo não apresentava esta habilidade, registrando e divulgando as suas composições através de discos, cedendo os direitos autorais aos proprietários das indústrias fonográficas.

Quanto à divulgação do termo tempo e gênero musical, podese concluir que a larga divulgação do tango argentino, em fins da década de 1920, no Rio de Janeiro, contribuiu para que o tango brasileiro pouco a pouco desaparecesse, dada a ambigüidade do nome com aquela dança e, ainda, as contradições internas relacionadas anteriormente. O surgimento do samba despertou a preferência entre as camadas subalternas.

\section{NOTAS}

1. ZAMACOIS, Joaquín. Curso de formas musicales. 6. ed., Barcelona, Editorial Labor, 1985, p.4.

2. SIQUEIRA, João Baptista. Três vultos históricos da música brasileira. Rio de Janeiro, Edição do Autor, 1969. p.29.

3. O título de nossa tese de Doutorado, sob a orientação do Prof. Dr. Arnaldo Daraya Contier, estabelecia essa necessidade de interpretação: Os tangos brasileiros. Rio de Janeiro 1870-1920.

4. TINHORÃO, J. R. Pequena História da música popular brasileira; da modinha ao tropicalismo. 5. ed., São Paulo, Art Editora, 1986. p. 69.

5. EFEGÊ, Jota. Maxixe: a dança excomungada. Rio de Janeiro, Conquista, 1974.

6. TINHORÃO, J. R. ibid., p.72.

7. Verifica-se que essa crítica de Nazareth aos andamentos rápidos exagerados não tem sido acatada pela maioria de seus intérpretes pósteros.

8. KIEFER, Bruno. Música e dança popular: sua influência na música erudita. Porto Alegre, Movimento,1986. p. 12. 
9. VASCONCELOS, Ary. Panorama da música popular brasileira na belle époque. Rio de Janeiro, Liv. Sant'Anna, 1977. p. 15.

10. Recentemente (1997), foi publicada pelo Centro de Pesquisas Folclóricas da Escola de Música da Universidade Federal do Rio de Janeiro, a obra Música popular gravada na segunda década do século, de autoria da professora Dulce Martins Lamas, com revisão minuciosa da professora Rosa Zamith, que apresenta um catálogo importante deste acervo trazendo novas luzes sobre este tema.

11. FRANCESCHI, Humberto. Registro sonoro por meios mecânicos no Brasil. Rio de Janeiro, Studio HMF, 1984.

Paulo Roberto Peloso Augusto é professor adjunto do Departamento de Composição da Escola de Música da Universidade Federal do Rio de Janeiro. 